\title{
Building on adaptive capacity to extreme events in Brazil: water reform, participation, and climate information across four river basins
}

\author{
Maria Carmen Lemos ${ }^{1} \cdot$ Bruno Peregrina Puga $^{2} \cdot$ Rosa Maria Formiga-Johnsson ${ }^{3} \cdot$ Cydney Kate Seigerman $^{4}$
}

Received: 4 May 2019 / Accepted: 27 March 2020 / Published online: 27 April 2020

(C) The Author(s) 2020

\begin{abstract}
Building the capacity of water systems to prepare and adapt to climate-driven events has become an important goal for water managers in Brazil. One aspect of building adaptive capacity (AC) is the ability of organizations and actors within these systems to apply techno-scientific knowledge (TSK), in particular, climatic information, to plan and respond to extreme events. However, the way the use of knowledge interacts with theorized determinants of AC, such as stakeholder-driven governance and democratic deliberation, remains relatively unexplored in the empirical literature. In this article, we propose a simple heuristic to understand the relationship between the use of climate knowledge and participatory management and explore it empirically in the context of integrated water resources management (IWRM) in four river basins in Brazil. We find that despite an overall increase in the capacity of the basins studied to manage drought through time, the relationship between use of TSK and participation is not straightforward. Rather, knowledge use to inform decision-making remains mostly insulated, with few groups controlling both the process of producing knowledge and making decisions in times of crisis. Yet, across all cases, the continued exposure of river basin organizations (RBOs) to TSK suggests a growing appreciation for the role of information in supporting action and increased efforts by RBOs to develop their own knowledge resources to become more relevant in the decision-making process.
\end{abstract}

Keywords Adaptive capacity $\cdot$ Water governance $\cdot$ Climate knowledge $\cdot$ Participatory management

Communicated by Debbie Ley

Electronic supplementary material The online version of this article (https://doi.org/10.1007/s10113-020-01636-3) contains supplementary material, which is available to authorized users.

Maria Carmen Lemos

lemos@umich.edu

1 School for Environment and Sustainability, University of Michigan, Ann Arbor, MI 48109, USA

2 Graduate Program in Development Economics, Federal University of Paraná (UFPR), Curitiba, Paraná 80210-170, Brazil

3 Department of Sanitary and Environmental Engineering, Rio de Janeiro State University (UERJ), Rio de Janeiro, RJ 20550-900, Brazil

4 Department of Anthropology, University of Georgia, Athens, GA 30602, USA

\section{Introduction}

In Brazil, the growing rates of extreme climate-driven events, especially drought, have challenged the ability of the country's water management institutions and organizations to prevent and respond to the impacts of these events. While floods and periods of drought occur in all climates globally (Mishra and Singh 2010), we examine multiple-year droughts that posed significant challenges to water managers. Between 2013 and 2016, an unprecedented drought affected 48 million people, with one-fourth of all Brazilian cities (1296) having declared a state of emergency due to drought or flooding by 2017 (ANA 2017). In Northeast Brazil, the drought - one of the worst in 500 years - has had devastating impacts on the region's water resources and on the livelihoods of its residents (Lemos et al. 2016). In the city of São Paulo, a record water supply crisis has revealed major inefficiencies in the city's water infrastructure and management that will reverberate for years to come (Empinotti et al. 2018). 
In 2017, Brazil's comprehensive water management reform reached its 20-year mark. Historically, water management in Brazil had been mostly top-down, sectoral (i.e., with water quality separated from quantity), centralized, and conflictridden (Formiga-Johnsson et al. 2007). Since 1997, however, the federal government has implemented a broad integrated water resources management (IWRM) reform that decentralized water management and shifted jurisdiction from the federal and state spheres to river basin organizations (RBOs) at the watershed level ${ }^{1}$. These organizations in turn became responsible for water planning and the mediation of conflicts and tradeoffs among different users. The RBOs included the all-encompassing River Basin and Sub-basin Committees (RBCs), as well as, other organizations, such as users' commissions, river basin Technical Working Groups, and water policy councils that are not only open to the public but are also supposed to pursue public participation actively. The processes through which the new water governance structures were created and through which they have evolved vary considerably throughout Brazil, in part due to the vagueness of the federal water management reform mandate (Abers and Keck 2006). Some river basin governance systems have become very complex with the involvement of countless organizations and a diversity of jurisdictional conflicts depending on their socio-ecological, economic, and hydrological characteristics (Libanio 2018; OECD 2015).

To date, the outcomes of the implementation of Brazil's reform have been mixed. Despite the commitment to integration and ecosystem-based management, in practice, it has been difficult to include and integrate across a wide range of natural and social aspects of water management. The reform has faced challenges in creating representative basin-level organizations, and decision-making within these bodies has been fraught with issues of participation, paralysis, and power inequities (Abers 2007; Taddei 2011). Even with the adequate development of new management structures, increasing the scope of participation can often lead to greater conflict, problems with accountability within the new structures, or the resurfacing of pre-existing domination by entrenched interests (Blomquist et al. 2005). For example, Abers and Keck (2006) describe how placing power in deliberative institutions created by the reform has often led to conflict rather than collaboration, which has strained the formation of new institutions as existing bureaucracies resist losing power.

Many of the characteristics of the new forms of governance implemented as part of the Brazilian reform (e.g., integrated water management, participatory water allocation, polycentric

\footnotetext{
${ }^{1}$ The new water law encompassed a decentralization reform, which defined the water basin committees as the main management unit. The committees are composed by state (federal, state, and municipal) and non-state actors (private users, NGOs, and universities) and have different roles and responsibilities, including planning, conflict-solving, and water bulk pricing. See detailed composition across case studies in the supplementary section.
}

governance, and the use of scientific knowledge to inform adaptive management) have been theorized to increase the adaptive capacity of governing units to respond to climate stressors. They have also been often offered as an antidote to technocratic decision-making and the means to garner buy-in and equity in water management (Lemos and Oliveira 2004; Hill 2012; Kiparsky et al. 2012; Knieper and Pahl-Wostl 2016). Yet, empirically, there has been relatively little research either exploring how these factors influence adaptive capacity building in practice or how they interact with each other, both in terms of synergies and tradeoffs (Engle and Lemos 2010; Engle et al. 2011).

In this article, we explore how two theorized determinants of adaptive capacity - participatory decision-making and the use of knowledge - relate to each other, positively and/or negatively, and how this relationship ultimately influences the capacity of different RBOs to adapt to climate stress. We examine the synergies and tradeoffs between the use of climate information and participatory water management in four Brazilian river basins (Médio and Baixo Jaguaribe [MBJ], Paraíba do Sul [PDS], Alto Tietê [AT], and Piracicaba-Capivari-Jundiaí [PCJ]), which have experienced severe drought in the past 20 years. In many ways, these river basins are ideal to assess the role of technoscientific knowledge (TSK) in building on adaptive capacity since they all possess active RBOs, have access to climate and hydrological information and models, and have traditionally created and deployed technical groups to advise management, especially to respond to climate-related crises. These river basins are also important socioeconomically, serving an estimated 40 million people over large expanses of Brazilian territory. While many different types of knowledge are involved in the decision-making processes of these basins (e.g., TSK, experiential, and co-produced), in this article, we specifically focus on the use of TSK during two drought periods between 2000 and 2016 and how it intersects with participation. We rely primarily on documentary and qualitative data (e.g., key informant interviews and participatory observation $)^{2}$ to explore a simple heuristic to understand the relationship between knowledge and participatory management and how this relationship may influence the capacity of the river basin governance systems to prevent, respond, and adapt to drought.

In the next sections, we review the literature focused on knowledge, governance, and adaptive capacity that informs the development of our heuristic. We then describe the cases and discuss the empirical data relative to the heuristic. We conclude by analyzing each case longitudinally across two drought events and suggesting how our

\footnotetext{
${ }^{2}$ See detailed description of methods in the supplementary materials section.
} 
findings may inform the building of adaptive capacity in water decision-making.

\section{Climate knowledge, adaptive capacity, and management of socio-ecological systems}

Climate knowledge, adaptive capacity, and management In principle, climate knowledge can contribute to more effective water management by informing stakeholders about system capacity and fluctuations, potential disruptions to resource availability (e.g., drought or flooding), implications of intraand inter-basin water transfers, long-term availability, and intergenerational implications of different levels of resource use (i.e., climate change impact scenarios) (Lemos 2008; Trenberth and Asrar 2014). In addition, knowledge can potentially democratize and improve the effectiveness of decisionmaking, since better-informed stakeholders should be more equipped to make decisions (Medema et al. 2017). However, if controlled by a few actors seeking to boost their position relative to others, knowledge can insulate and limit the scope of decisions and decision-makers, intensifying power imbalances between those with access to knowledge and those without (Lemos 2008; Lundmark and Jonsson 2014; Morrison et al. 2017). In this sense, knowledge use can lead to the technocratization of decision-making, which, in turn, may affect equity and sustainability in water management. The difference between democratization and technocratic insulation may depend on the rules of engagement of stakeholders ("rules of the game"), the values and beliefs of technocrats, and the practices regarding availability and accessibility of knowledge (Lemos and Oliveira 2004; Lemos 2008). Furthermore, poor assumptions based on climate knowledge can also hurt users rather than help different stakeholders, such as in the case of the application of a "wrong" climate forecast or when forecasts are applied with negative societal outcomes, such as civil unrest and mass layoffs (Broad et al. 2002).

Knowledge use is also essential to adaptive co-management, which has become a core theme in adaptation research and is considered a means by which the resilience and adaptive capacity of socio-ecological systems (SES) increase (Folke et al. 2005; Nelson et al. 2007). Governance strategies better suited to manage the uncertainty and non-linearity of complex socio-ecological conditions often argue for multilevel interactions between actors, new ways of generating and distributing scientific information, and better linking of science to policy (Morrison et al. 2017; Armitage and Plummer 2010; Berkes 2009; Davidson-Hunt and O'Flaherty 2007).

Scholars have long pointed out that the more adaptive capacity there is within a system, the greater the likelihood that the system will be resilient in the face of environmental stress (Hill 2012). For example, Armitage and Plummer (2010) argue that adaptive capacity is fundamental to adaptive environmental governance, as it enables human and natural systems to respond to and recover from environmental stress, such as pollution or climate change. Scholars have argued that adaptive capacity is determined by the level of and interaction between resources (e.g., economic, human, cultural, political, technical, and information), skills, infrastructure, institutions, equity, social capital, and collective action (Smit and Wandel 2006; Yohe and Tol 2002).

There are two important temporal aspects of adaptive capacity. First, adaptive capacity is critical for a system, or for the actors that constitute the system, to cope in the short term to maintain the status quo (i.e., resilience). Second, adaptive capacity is important to facilitate transitions and transformations-long-term adaptation directed to more desirable states (Nelson et al. 2007). For adaptive capacity to aid in the governance of complex socio-ecological systems, it must be understood as a long-term social process involving institutional and social learning, as well as a diversity of social actors and issues, which takes place on multiple scales and engages with diverse perspectives and epistemologies (Armitage and Plummer 2010). While a range of frameworks has been used to theorize adaptive capacity building, few empirical studies actually assess adaptive capacity against these determinants, and even fewer do so relative to water management (Engle 2011; Lemos 2015).

Participatory decentralized governance New forms of natural resource governance such as IWRM, adaptive water management (AWM), and adaptive co-management (ACM), in principle, should foster adaptive capacity. In IWRM, river basinlevel organizations should include representation of all relevant stakeholders within the established river basin boundaries, including water users, civil society, and officials from the various administrative units within or overlapping the basin (Medema et al. 2008). The broad representation of stakeholders often produces polycentric and horizontal integration of multiple institutions across scales by bridging networks into a new boundary organization at the basin scale (Pahl-Wostl 2007). Because AWM involves experimentation, learning, and change and requires an organized science base, it allows for the formulation and evaluation of testable hypotheses (LoSchiavo et al. 2013). Similarly, adaptive co-management is characterized by flexible, community-based management programs that both enable dynamic learning and enhance the flow of different sources and types of knowledge across scales of governance (Olsson and Folke 2003). Research has illustrated that the character of social interactions (e.g., inclusivity, exclusivity, bridging, or bonding), the systems for knowledge transfer and learning, participation, and collaboration are important in order to enhance adaptive capacity and resilience (Berkes et al. 2000; Newman and Dale 2005; Olsson and Folke 2003). In theory, by emphasizing participation and 
democracy, AWM and IWRM bring together knowledge and governance.

Hence, the participatory character of IWRM should provide an arena for deliberative decision-making and planning processes that involve the broad participation of users, civil society, and public officials in the domain of the river basin. Through reform that organizes interests at the basin level, all sectors and interests are involved, ideally leading to cooperative and deliberative action that can limit water conflicts (Genskow and Born 2006). Explicit recognition of multiple, and often competing, interests through collaborative actor platforms allows for the transparent and democratic assessment of tradeoffs and the negotiation of priority uses of water to create integrated management plans (Savenije and Van der Zaag 2008). Elements of actor inclusion and basin decentralization should also improve the effectiveness, transparency, and accountability of water management (Jaspers 2003). These democratic and participatory decision-making processes, in turn, should be instrumental in facilitating discussion around adaptation and in building on adaptive capacity.

Yet, empirical testing of the relationship between democratic decision-making and adaptive capacity is relatively rare and does not always indicate a positive relationship. For example, based on a survey of over 600 river basin committee members, Engle and Lemos (2010) developed quantitative indicators of adaptive capacity across eighteen river basin communities in Brazil. While they found that there might be a positive relationship between adaptive capacity and the decentralized governance structures of the Brazilian water reform, tensions and tradeoffs may exist between equality of decision-making and availability of knowledge. Factors such as pre-existing power relationships, entrenched bureaucracies, and lack of resources can thwart the successful implementation of governance, including the expansion of democratic participation. The legacy of existing institutional dynamics and the use of technical knowledge can create path dependencies that negatively affect flexibility and the ability of RBOs to make decisions (Engle et al. 2011).

\section{Building on adaptive capacity for water decision-making}

In this study, we theorize that two factors help shape adaptive capacity in response to extreme events: the level of participatory democracy and the use of scientific knowledge to inform decision-making about water use and scarcity (Fig. 1) (Broad et al. 2002; Engle and Lemos 2010; Kirchhoff et al. 2013; Pfaff et al. 2013). We build a typology of adaptability in which systems where knowledge use is high, knowledge is available and accessible, and decision-making is democratic (i.e., participatory, transparent, accountable, diverse, and inclusive in terms of the range of stakeholders) have the highest levels of adaptive capacity. Systems where governance mechanisms are participatory but lack appropriate knowledge to inform management may lead to poor decision-making and potential unsustainable use of resources and response to stressors, potentially decreasing adaptive capacity. Systems with high levels of knowledge use but where decision making is less than democratic are technocratically insulated. In this conceptualization, knowledge use is limited to experts, and significant levels of inequity exist between experts and non-experts. Technocratic insulation, in turn, can lead to lack of "buy-in" among stakeholders, low levels of stewardship, and increased non-compliance with decisions, ultimately resulting in lower levels of adaptive capacity. Alternatively, however, technocratic insulation can further mobilize stakeholders to recapture their role as decision-makers at the river basin committee level, steadily moving outcomes toward greater adaptability in a polycentric context. Finally, systems with low levels of democracy and knowledge use will likely be maladaptive, showing the lowest levels of adaptive capacity as resources are likely to be poorly managed. Figure 1 shows the four functional types of adaptive capacity. In proposing this heuristic, we aim to understand the possibility of synergy and tradeoff between two determinants of adaptive capacity while recognizing that it offers a critically limited account of all factors affecting adaptive outcomes. We take both a historical perspective (taking advantage of data collected in the early 2000s) and a current assessment of how this relationship might have evolved through time.

\section{The case studies}

Table 1 Characteristics and main governance actors and organizations of the case studies

Médio and Baixo Jaguaribe river basins Since the late 1990s, the two basins created participatory structures to discuss and make decisions about water allocations of their largest dams (for a detailed discussion, see Seigerman and Nelson 2019). Before 2018, during the annual plenary allocation session, COGERH water managers, or "técnicos," would present to participants a myriad of technical information including (1) dam operating conditions, water capture volumes, and user demands; (2) pre-crafted allocation scenarios for reservoirs in the basin; and (3) proposals for irrigation regulations to the five Jaguaribe sub-basin committees and the FortalezaMetropolitan Committee. Then, committee members were given an opportunity to voice their opinion regarding water allocation in the region before the general vote on the scenarios for the three main dams (Lemos 2008). In 2018, a Working Group (WG) was formed at the request of the committees in order to increase their participation in the management of water in the system. ${ }^{3}$ During a WG meeting prior to the

\footnotetext{
${ }^{3}$ See the supplementary material for more details about the WG and scenarios.
} 
Fig. 1 Typology of adaptability regarding participatory/ democracy mechanisms and knowledge use

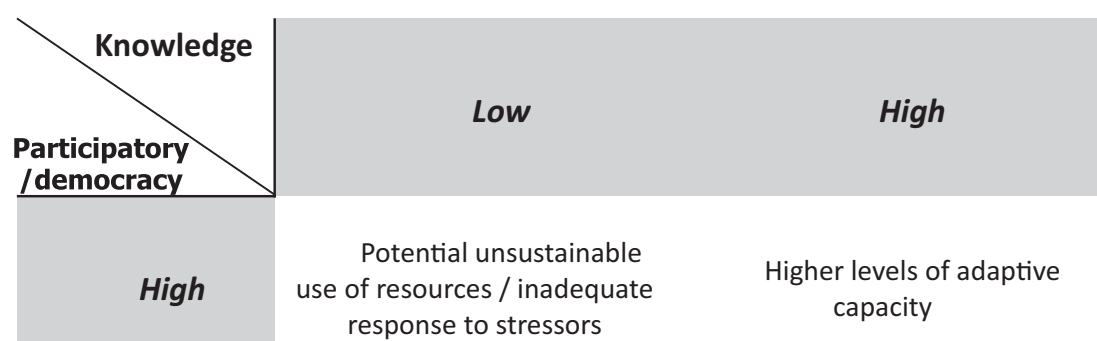

Technocratic Insulation, alienation of stakeholders /lack of buy in
Maladaptation

Table 1 - Characteristics and main governance actors and organizations of the case studies

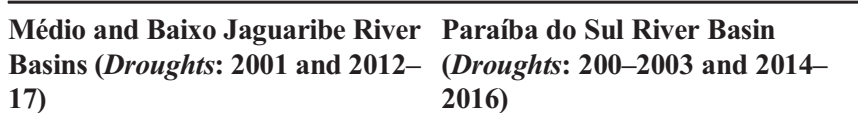

ocation and importance: Loca
in the northeast state of Ceará, they encompass 22 municipalities over $17,384 \mathrm{~km}^{2}$ of drainage area They are one of the main water sources for the metropolitan area of Fortaleza, the capital of Ceará. Fortaleza is located outside of the basins and is home to over four million people; it is considered one of the three most important metropolitan areas in northern Brazil. Extreme events and droughts are a permanent threat to the semi-arid region in which Fortaleza and Médio and Baixo Jaguaribe basins are found. The region experiences irregular rainfall patterns and significant hydrological variability between seasons.

Main Organizations:

- Users' Commission: Made up of water users and representatives of civil society in the Jaguaribe Valleys. The commission met yearly to discuss and make recommendations regarding reservoir water release and use (e.g., irrigation) until 2004 when it was absorbed into the River Sub-basin Committees

- River Sub-Basin Committees: Composed of representatives of different water-user groups, different levels of government, and civil society. The Committees operated in parallel to the Commission for a few years and completely replaced it in 2004. The River Sub-Basin Committees
Piracicaba-Capivari-Jundiaí River Basin (Droughts 2003-2004 2003-2004 and 2013-2015) and 2013-2015)
Alto Tietê River Basin (Droughts:

\section{Location and importance: Located Location and Importance:} in the southeast region across three states (Rio de Janeiro, São Paulo and Minas Gerais), which makes it a basin under federal jurisdiction as well as each state's jurisdiction. It encompasses 184 municipalities, over an area of $61,307 \mathrm{~km}^{2}$. The basin is highly industrialized and urbanized. The growing demand for water is largely fulfilled by the Paraíba do Sul-Guandu System, a complex infrastructure system initially built for energy generation and currently used for multiple purposes. The basin supplies water for 6.3 million people within the basin and over 12 million through inter-basin water transfers to the metropolitan areas of São Paulo and Rio de Janeiro. These transfers lead to intense conflicts between states and different user groups on issues including water supply and quality and allocation to different uses (e.g., industry and urban supply). Such conflicts are exacerbated during drought events.

Main Organizations:

- National Water Agency (ANA): Main water authority in the basin. It is in charge of water-use regulation of federal rivers and the coordination of the IWRM in the whole basin.

-State Water Management Agencies (INEA-RJ; DAEE-SP; and IGAM-MG): these are
Located in the southeast across the states of São Paulo and Minas Gerais. It encompasses 76 municipalities over $14,178 \mathrm{~km}$, including the Campinas Metropolitan Region, an important technological and industrial center and home for 5,5 million people ${ }^{2}$. Home of the "Cantareira System", responsible for almost half of water supplied to the São Paulo Metropolitan Region. Since its construction the system has been a source of major conflicts since it siphons water from the basin to São Paulo decreasing water availability.

Main Organizations:

-River Basin Committees: There are three committees in the basin: one federal and two sub-basin committees, one in São Paulo and one in Minas Gerais. Each committee is made up of representatives of different user groups, different levels of government, and civil society. The main arenas for deliberations - SABESP (State water company): happen within 12 Technical chambers, comprising 600 members.

- Consórcio PCJ (River basin Consortium): Created in 1989 by municipalities and private users as an important arena to water resources discussion. It was the first executive agency of the committee until the creation of the Agência PCJ in 2009.
Location and Importance: The Alto Tietê river basin overlaps with São Paulo Metropolitan Region, the largest urban area and most important socio-economic center in South America. Located in the headwaters of Tiete river, the basin is highly polluted and plagued by persistent problems of water availability. It supplies water for over 21 million people through 9 water systems, most of them fed by water transfers from other basins. The largest one, the Cantareira System, has close to half of its water supplied by the PCJ Basin.

Main Organizations:

- River Basin Committee: created in 1991 is constituted by water users and representatives of civil society. In 19975 sub-basin committees were created.

- FABHAT (River basin agency): created in 2002 as a water agency but plays a limited role due to lack of financial and technical resources.

Mixed capital company $(51 \%$ state and $49 \%$ private shareholders) and is responsible for the management of Sistema Integrado which supplies water for 33 of the 39 municipalities in the basin.

- DAEE (state water regulatory agency): responsible for water management at the state level, including pricing and charging. 
Table 1 (continued)

Médio and Baixo Jaguaribe River Paraíba do Sul River Basin

Basins (Droughts: 2001 and 2012- (Droughts: 200-2003 and 201417)
Piracicaba-Capivari-Jundiaí

River Basin (Droughts 2003-2004

Alto Tietê River Basin (Droughts: and 2013-2015) participate in an annual plenary session with the three other river sub-basin committees in the Jaguaribe Valley and the Fortaleza-Metropolitan committee to make allocation decisions for the state's three largest dams: Castanhão, Orós, and Banabuiú Dams. They also set regulations for water use along the Jaguaribe River.

- Grupo de Trabalho (Working Group): Formed in 2018 by the initiative of the sub-basin committees and comprised of 18 members, with three representatives from each of the five sub-basins and the Fortaleza-Metropolitan river-basin committee. The Group meets monthly to discuss the Jaguaribe-Fortaleza Metropolitan system.

- State Water Resources Council (CONERH): Consists of representatives from different state offices, industrial users, civil society, and one representative for the twelve river basin committees in Ceará. The Council has the ultimate decision-making authority regarding decisions made about trans-basin water transfers, such as water allocation from the Castanhão Dam to Fortaleza.

- Ceará State Water Company (COGERH): Responsible for the management of the state's water resources. It has a highly trained cadre of water managers (técnicos) and oversees the operations of the state's hydraulic system, including the bulk water charge system and bulk-water allocation. It also acts as the executive secretary of the river basin committees in Ceará. organizations responsible for the regulation of each state water use. -River Basin Committees: There are eight committees in the basin: one federal committee covering the whole watershed (CEIVAP) and seven state committees at the sub-basin level (one in São Paulo, two in Minas Gerais, and four in Rio de Janeiro). The committees' main roles include: mitigating water conflicts, approving river basin plans, and overseeing regional water pricing and charging.

- GTAOH/CEIVAP (Technical Working Group of CEIVAP): Responsible for water allocation proposals and conflict mitigation related to the Paraíba do Sul-Guandu Hydraulic System during drought. Reports to ANA, which has the final word on management decisions.

-AGEVAP (River Basin Agency): Executive body of CEIVAP and six states committees (except the SP Committee)

ONS (Operador Nacional do Sistema Elétrico): A private agency funded by the hydropower sector to coordinate and optimize reservoir operation for hydropower use defined by ANA and state authorities.
- Agência PCJ (River basin agency): Executive body from PCJ committee created in 2009. It manages pricing and charging and provides technical support to the committee.

- SABESP (State water company):

Mixed capital company $(51 \%$ state and $49 \%$ private shareholders) and is the main water user in the basin. It is responsible for the operation of the Cantareira System, which supplies the São Paulo Metropolitan region.

-National Water Agency (ANA): Main water authority in the basin. It is in charge of water-use regulation of federal rivers and overall management coordination, including the renewal process for water allocation through interbasin transfer.

- GT-Estiagem (Drought Working Group): temporary workgroup tasked with providing advice about coping strategies and actions (mainly by water supply and treatment utilities and municipalities) during drought crisis.

- GTAG-Cantareira (Technical Working Group): workgroup responsible for the management of the Cantareira System during drought crises. Composed by ANA, DAEE, Sabesp and representatives from $\mathrm{PCJ}$ and the AT basin.

- Ministério Público (State Attorney's Office): Both Federal and state MP were important actors in defense of public interests, by using public suits and civilian inquiries against water companies and state water agencies during the crisis. plenary RBC allocation session in June 2018, COGERH técnicos presented proposals for the allocation scenarios and regulations to be presented at the plenary meeting later that month. The scenarios were based on a very conservative strategy by simulating conditions based on the lowest rainfall year (2016) of the last 8 years of drought. The WG debated the presented proposals and questioned some of the technical information provided by COGERH, including the water demands for Fortaleza and the Jaguaribe Valley. When no decision was reached, a second meeting was scheduled, during which COGERH técnicos presented revised proposals to respond to the WG's earlier questions. The revised proposals were further discussed by WG members and COGERH técnicos and amended into new scenarios and restrictions. The Baixo Jaguaribe RBO subsequently held an additional meeting to discuss the scenarios finalized by the WG. 
During this meeting, COGERH técnicos presented technical information, while the three members of the WG acted as brokers, explaining alongside the COGERH técnicos the meaning of the scenarios and possible implications of these scenarios for the region. The Baixo for consistency Jaguaribe $\mathrm{RBC}$ decided on an allocation scenario for the largest reservoir to be proposed at the broader Committee plenary session.

At the plenary allocation session, the state meteorological organization, the Fundação Cearense de Meteorologia e Recursos Hídricos (FUNCEME) presented climate information, including past drought trends and possible conditions for the following year, before the presentation of the scenarios by COGERH. During the meeting, each dam and its related regulations were discussed individually, and Committee members were given time to express their opinion after each presentation. Up to this point, the process of negotiated allocation had followed a traditional pattern in the meeting, with técnicos from FUNCEME and COGERH mostly dominating the discussion process. However, in contrast to the almost two decades of previous negotiation, two additional scenarios were proposed by Committee members for two of the reservoirs. For the largest reservoir (Castanhão), the newly proposed scenarios increased the overall amount of water released from the dam, decreasing the amount of water for Fortaleza and increasing the amount for the Jaguaribe Valley. In the case of the two largest reservoirs, Committee members chose a scenario proposed during the plenary session and not the scenario developed by the WG and COGERH. Because the Committee voted to decrease the amount of water delivered to Fortaleza from the Castanhão, directly challenging the acceptable values determined by COGERH and the state, the decision was reviewed by the State Water Management CommissionCONERH, which has ultimate decision power in case of disagreement among the several lower level organizations involved in the process.

Outcomes: Historically, the negotiated allocation process has worked well in avoiding the kind of extreme water scarcity that plagued the basin prior to the water reform (Lemos 2008). In 2018, CONERH ultimately rejected the RBOs' proposal, maintaining the previously established water flow to Fortaleza. While the establishment of the WG reflected increased participation by the committee in the creation of allocation scenarios, COGERH técnicos ultimately continued to control knowledge access by not fully disclosing the simulation conditions used to create the original proposals presented to the WG. According to the técnicos, the use of highly conservative scenarios was necessary to avoid the collapse of the Jaguaribe-Fortaleza integrated dam system and to guarantee water to Fortaleza.

Paraíba do Sul river basin The main water committee, Comitê para Integração da Bacia Hidrográfica do Rio Paraíba do Sul (CEIVAP) -composed of managers, users and civil society representatives-followed similar strategies to manage the water crises of 2001-2003 and 2014-2016. In both cases, CEIVAP created an influential Working Group (GTAOH) that met often to define scenarios and advise both CEIVAP and Brazil's National Water Agency (ANA). During both crises, although ANA had the ultimate decision-making power, it systematically accepted the advice provided by GTAOH/ CEIVAP about strategies to reduce water use, water reallocation, and adaptive actions in order to ensure multiple-use supply during drought events. An important part of the basin's approach to water management, especially in times of crisis, is defined by the need to increase water security of São Paulo and especially Rio de Janeiro, two of Brazil's largest cities. Although both metropolitan areas are located outside the Paraíba do Sul watershed, inter-basin transfers connect the two cities to the river and the need to supply the two most populous and rich urban agglomerates in the country dominates decision-making in the basin. Moreover, the basin is also a major provider of hydropower, which historically have been managed outside of and in parallel to the water system, with the support of ONS (Organização Nacional do Sistema), a powerful private organization funded by the power sector to generate its own climate information. In previous crises, ONS and the hydropower sector acted mostly unchecked despite the increasing role of CEIVAP's technical groups as advisers for ANA in the management of drought events (FormigaJohnsson et al. 2007).

Traditionally, the Paraíba do Sul river basin has followed a very risk-averse pattern of decision-making. The prevailing approach used in response to the 2001-2003 and 2014-2016 droughts assumed severe drought conditions for an indeterminate future, with the goal of saving as much water as possible in the basin's four storage reservoirs. In the 2014-2015 drought, however, as the drought persisted, CEIVAP and ONS cooperated in creating new scenarios reinforcing the need to save water in the reservoirs and to encourage users to adopt adaptive strategies to decrease water use. At the peak of the crisis, reducing supply to industrial users became inevitable to guarantee water supply to the city of Rio de Janeiro. Even with the end of the meteorological drought in 2015, managers opted to continue following a conservative approach, keeping water in the reservoirs until they were completely replenished in late 2016. ${ }^{4}$ Although technical knowledge was available in both crises, its use and robustness were much higher in 2014-2016, in part because of increased and better-integrated cooperation between state water managers and ONS. In addition, the decision making process was more transparent, as the most relevant discussions held within the technical chamber were well documented and made public in 2014-2016.

\footnotetext{
${ }^{4}$ The minutes of GTAOH meetings are available on http://www.ceivap.org.br/ ophidraulica.php.
} 
Outcomes: In 2001-2003, the water supply was maintained in the Paraíba do Sul basin and city of Rio de Janeiro despite a few shortage issues that were quickly addressed. During the 2014-2016 drought - the worst in 85 years of historical data - the water agencies were able to save $77 \%$ of water storage $\left(3342 \mathrm{hm}^{3}\right)$ and also avoided supply shortages by implementing successive adaptive actions. Nonetheless, some water users and large industries were critically affected. The supply of water to several mid-size municipalities was also impacted. Overall, the most important outcome in terms of management was the institutional change in the reservoir operation rules, which made management more adaptive to drought by increasing the water security for multiple uses and restraining the flexibility for power generation (Formiga-Johnsson et al. 2019).

Piracicaba-Capivari-Jundiaí river basin The PCJ river basin has traditionally been very active and diverse, with several management structures co-existing and overlapping. The basin governance is strongly shaped by the need to supply water to the Cantareira system, which serves the São Paulo Metropolitan Region (SPMR). Most of the PCJ river basin water is transferred to the Alto Tietê (AT) basin through the Cantareira system and decision making in the basin has been heavily controlled by the state water sanitation company, Sabesp, its main water consumer. Until 2003, Sabesp was entitled to use all the water it needed, without any guaranteed minimum flow for the PCJ basin. However, as a result of the 2003 drought, the inadequacy of this scheme came to the fore and a new water permit system was created that started a shared management approach in the Cantareira system. This shared approach included both broader participation of the RBOs and efforts to reduce the role of the Cantareira system in supplying water to the city of São Paulo. After the crisis, to avoid a potential water collapse in the PCJ basin, Sabesp, ANA, and the RBOs introduced water banks and riskaversion curves as two new planning instruments. Yet, despite these innovations, Sabesp remained the primary decisionmaker, leaving little room for RBO members' participation. In 2013, even with historically low rainfall, Sabesp continued to withdraw all of the water it had been granted without adjusting for water decline in the system. But as the crisis deepened with the worsening situation of the Cantareira, the political and public outcry about water scarcity opened the door for the Technical Working Group (GTAG) to take over the management of the reservoir, with ANA and the state water management agency (DAEE) making decisions with the participation of representatives of the PCJ and AT RBOs,

\footnotetext{
${ }^{0}$ For further details and references supporting the discussion, see supporting case description for each basin in the Supplemental Material section.
}

in addition to Sabesp. However, a public political fight between ANA and DAEE a few months later resulted in ANA leaving the GTAG, in effect dispelling the GTAG. The lack of inclusion in the decision making process of a broad coalition of actors resulted in growing dissatisfaction and complaints from the RBOs and demands for access to information from Sabesp and state agencies. Additionally, because of the crisis, the renewal of Sabesp's withdrawal permit, scheduled to happen in 2014, was postponed and the discussions about what to do lasted until 2016. In the end, despite infighting between state and federal organizations, further negotiations between the state of São Paulo and the federal government guaranteed the financing of the water transfer infrastructure from the Paraíba do Sul river basin to Cantareira.

Until 2004, PCJ RBOs had little access to information regarding the Cantareira operation. The main planning tool (basin plan) provides a 10-year scenario and allocates resources according to the priorities of the PCJ technical groups. The plan mostly relies on demographic, economic, and water demand projections, and includes few provisions for the planning and prevention of impacts of extreme events. The main water allocation discussion occurred during the water permit granting process for the Cantareira system. After a severe flood in 2009-2010, a "situation room" was created where técnicos from the Technical Working Groups and Sabesp provided real-time monitoring and hydrological information to PCJ actors but the effort still did not include drought models or scenarios.

During the 2013-2016 crisis, the threat of water collapse in the Cantareira system triggered a more concerted effort to coordinate across all the systems supplying the SPMR. ANA took over control and acted as a strong alternative power to Sabesp and DAEE. In contrast to the 2003 drought, the PCJ Consortium gathered information and hired experts to provide alternative scenarios and mobilize PCJ basin actors. As a result, as of 2016, all of the Cantareira allocation decisions have to be made by CT-MH (PCJ water monitoring group), which gained more authority and now must base the water releases on hydrological scenarios.

Outcomes: While water rationing was avoided in both events, the two drought crises introduced new management instruments and stimulated PCJ organizations (RBOs and the Consortium) to seek and create their own techno-scientific information on which to base allocation decisions. The new norms fostered studies on strategies to reduce Sabesp's dependency on Cantareira system and also imposed new constraints on Sabesp's ability to make unilateral decisions. Finally, new requirements include a contingency plan, monitoring, management curves (supply vs. volume), a revision of hydrological principles shaping decisions, enhancement of the sewage treatment in the basin, rational use, and a focus on 
reducing the dependence of the city of São Paulo water supply on the PCJ river basin.

Alto Tietê river basin Sabesp is the main actor of the AT basin and is responsible for almost all management decisions. In 2003, a low rainy season and the continuous withdrawal of water from the basin resulted in the rapid depletion of the Cantareira reservoir, forcing Sabesp to implement water rationing for some neighborhoods and communities in the SPMR. Little discussion about the drought occurred within the AT RBOs, and crisis management was dominated by state actors, with low popular participation. Common wisdom claimed that managing the drought was a Sabesp problem. The AT RBOs questions to Sabesp were limited to clarifying what the company was doing to cope with the drought. Most of the data released about the operation of the reservoir were heavily controlled, showing only changing water levels. Most decision-making happened behind closed doors, with the RBO posing the odd question and getting perfunctory answers. The low technical capacity of the Committee and its water agency makes it an ineffectual and passive actor, that uncritically approves the state agencies' decisions. The process for the renewal of the water permit for the Cantareira system in 2004 happened mostly insulated from the participation of the RBOs, which sanctioned a decision already made by Sabesp and DAEE. Despite the drought and the rationing, little changed in the way Sabesp managed the water and the crisis, with RBOs actors having no access to information or decisions.

In 2013, the severe drought in Cantareira caused the worst water crisis in the SPMR. Despite the severity of the crisis, the AT RBO remained mostly disconnected from the discussion or decisions. However, unlike the 2003 crisis, the political and public outcry encouraged social movements in the region to mobilize and act as a societal watchdog, partly playing the oversight role ascribed to RBOs. The State Attorney's office also held several public hearings and collected public complaints, forcing state actors to act in a more accountable and transparent way. In response, Sabesp increased water transfers between systems, built new infrastructure, and established a bonus and fine program to reward or punish large water users. It also decreased tap water pressure and volume to individual households and businesses, implementing a de facto-albeit more palatable - water rationing program, which was the source of a great number of public complaints.

Regarding the creation and use of techno-scientific information, the AT RBOs had little capacity and depended on state agencies for all of its needs. All of the available information, scenarios, and models were provided by Sabesp or DAEE. Moreover, in 2003, most of the information and knowledge about water systems were confidential, including the level of the reservoirs. The AT RBO has limited technical capacity and financial resources to generate alternative scenarios, which contributes to the dominance of powerful actors (such as state actors and industrial users) over the agenda and discussions within the RBOs. In 2013, little changed in terms of active participation, but the discussions related to Cantareira and water crisis increased the level of knowledge available, with more pressure on state agencies regarding transparency. Conversations within the RBOs also increased, focusing mostly on the process for water permitting and transfer of resources from the AT to the Cantareira system. Finally, the State Attorney's office launched an investigation questioning the dominance of Sabesp and other state agencies over the RBOs as well as some of their actions, especially regarding information sharing and transparency.

Outcomes: Despite the ability of Sabesp and DAEE to avoid outright rationing, the crisis in the AT did little to shift the power balance between the RBO and state agencies. The role played by social movements and the State Attorney's office was instrumental in calling attention to the problems of the basin and instigating some action to increase the role of the RBOs. Overall, the capacity of the AT to be an active actor in managing extreme eventdriven crises remains low.

\section{Understanding tradeoffs between use of knowledge and participation in building on adaptive capacity}

In this study, we focus on whether different RBOs deployed TSK and if and how the way this knowledge was used made the decision-making process more inclusionary and participatory. We also explore if changes in knowledge use have built on the capacity of each system to respond to drought across time by analyzing two different drought-related crises. Overall, all systems studied increased their use of TSK over time and in the face of crises, albeit with marked differences in terms of sophistication and efficacy. ${ }^{5}$ All systems had access to weather and climate information (especially El Niño forecasting) and, with the exception of the Alto Tietê case, created and employed sophisticated scenarios to support decisionmaking.

The extent to which these scenarios were used and the level of input from RBOs varied significantly. In the Médio and Baixo Jaguaribe river basins, for example, técnicos from COGERH created increasingly sophisticated scenarios. The scenarios have been used since the early 2000s to support the allocation of reservoir water by RBOs between the urban,

\footnotetext{
${ }^{5}$ For further details and references supporting the discussion, see supporting case description for each basin in the Supplemental Material section.
} 


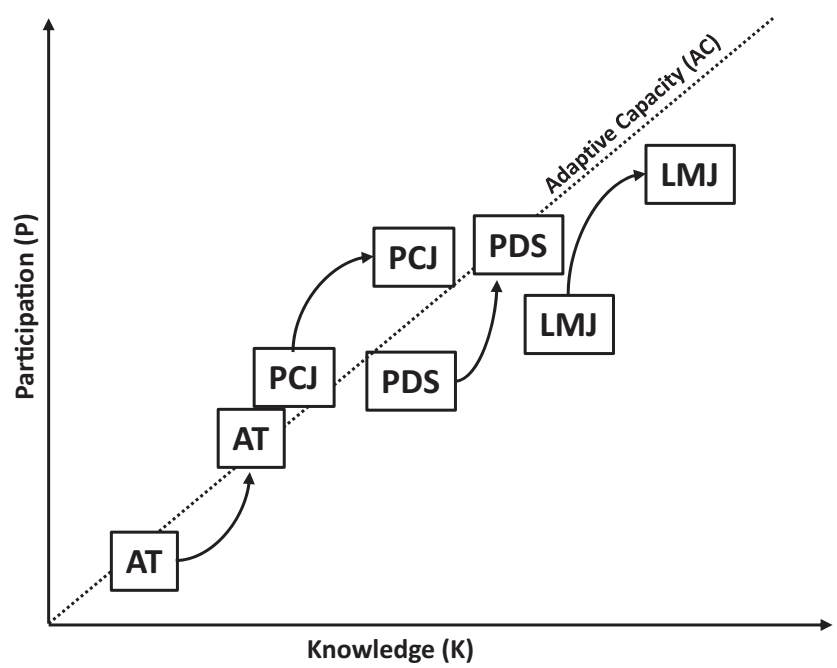

Fig. 2 Case studies in knowledge and participation heuristic based on data collected between 2000 and 2016

agricultural, and industrial uses in the region. Early on, these discussions were strongly controlled by COGERH técnicos and the use of information was less than transparent in terms of the rainfall projections included. More recently, however, the RBOs have pushed for increased transparency and say on how the scenarios are put together. In a sense, the continuous exposure of RBO members to the scenarios over the past 20 years has created an informed and empowered group of users that has started to push back and challenge the "authority" of COGERH técnicos as the only experts in the room. Over this period of time, a traditional area of contention between RBO members and state authorities has been the water supplied to the capital city of Fortaleza, which relies primarily on the reservoir system in the Médio and Baixo Jaguaribe RBOs. On the one hand, COGERH seeks to protect Fortaleza by pushing for decisions that take into consideration the need to supply water to the capital city for years to come. On the other hand, stakeholders in the river basins want more flexibility in decision-making and the release of more water to supply their needs. In 2018, this conflict became even more evident when a WG from the RBOs contested the conservative proposals made by COGERH técnicos. In the final vote, the RBOs decided on an even less conservative proposal than that proposed by the WG, which automatically shifted the decision to the CONERH, the highest authority at the state level to solve potential conflicts. In this sense, the tradeoff between knowledge and participation has shifted from a more insulated model to one in which users are more empowered and relevant. At the same time, water managers in the system have become more active in looking for additional solutions to supply water to Fortaleza, including a seawater desalination plant that is currently being studied. The combination of negotiated allocation and a more flexible range of sources of water for Fortaleza certainly made the system more adaptive. Moreover, the integration of all reservoirs, both in the scenario building and in the negotiation within the RBOs, rather than each one separately, made the system stronger in its ability to respond to crisis. Conversely, lack of control by the COGERH técnicos may lead to further challenges to established norms and the progressive increase in consumption levels by large users, especially agriculture.

In the Paraíba do Sul river basin, knowledge use increased with the system deploying even more sophisticated models and scenarios to respond to drought. The basin is complex and at times institutionally and spatially cumbersome, encompassing three states and multiple sub-basins and decision structures. This complexity has made democratic participation difficult politically and logistically, and CEIVAP (the federal committee for Paraíba do Sul River Basin) actions are often far removed from local realities. Because the basin involves three states, it is under the jurisdiction of the federal government and the National Water Agency (ANA), in addition to the state water management agencies and its own basin agency, AGEVAP. The system has also often created Technical Working Groups across the three states, which have been influential in terms of knowledge production and deployment. In addition, the hydropower sector has its own technical information organization (National System Operator (ONS)), which functions separately from the basin's Technical Working Groups. Traditionally, the multiplicity of actors across states and sub-basins has led to clashes over resource allocation and the macro-level vision for water management in the basin. But over time, the increasing legitimization of the Technical Working Groups as representative of the interests of the RBOs has made negotiations less contentious. The broadening of these groups between the 2001-2003 and the 2014 2016 droughts to include representatives of several of the stakeholder groups in the CEIVAP has smoothed the path for better representation in the more recent crises. Often, negotiations happen at higher spheres in and between the states, as well as through the strong dominance of the water supply, sanitation, and hydropower sectors. In this process, CEIVAP mostly acts as a referee on the decisions made at higher levels. Thus, although in the past the system saw itself as participatory, the number of actors involved was small and many of the negotiations lacked transparency. In the 2014-2016 drought, the decision-making process significantly improved in terms inclusion, level of participation, and transparency. For example, during the 2014-2016 crisis, although most of the negotiations were led by ANA, all minutes and documents from meetings were made available to the public. Similarly, during the 2003-2004 crisis, ONS and CEIVAP Technical Working Groups primarily worked separately. In the more recent crisis, they were able to coordinate and work more closely, with ONS being responsible for producing most of the climaterelated information. Yet, during both crises, the dominance of the técnicos characterizes a classic case of technocratic insulation, and CEIVAP overall supported the process once 
it was negotiated. Hence, while technocratic insulation appears to be eroding in the Médio and Baixo Jaguaribe river basin, it is alive and well in the Paraíba do Sul river basin. However, the fact that issues are agreed on prior to decision making and that consensus is built between CEIVAP and the Technical Working Groups, has led to scarce disagreement and limited the need for a higher sphere to intervene. Moreover, in the Paraíba do Sul river basin, the system has clearly become more adaptive in integrating better across interests and different uses and coming up with creative solutions to guarantee long-term resilience in the face of future threats. Although the preeminence of the hydropower sector over all other users had been untouchable in the past, operationalization rules have changed recently to establish a better balance between all interests.

Similar to the Paraíba do Sul river basin, the Alto Tietê river basin suffered water crises in 2003-2004 and 20132015. In the Alto Tietê river basin, the process was mostly dominated by Sabesp, which is publicly controlled, but with $49 \%$ of its stocks owned by private shareholders. The Alto Tietê RBOs have had a limited role in water management in the basin, as Sabesp strongly controls both water allocation decisions and the access to and availability of technical knowledge. In both drought events, all allocation and rationing decisions and the implementation of these decisions were enacted by Sabesp with little participation from the RBOs. Yet, in 2013-2016, as the crisis got worse and no good solution seemed to be in sight, the RBOs started to mobilize, contesting Sabesp's control by demanding access to information and transparency. Although the RBOs forced the issue with the then governor of the state of São Paulo, no decision was made. An often offered explanation for the governor's inaction was his vulnerability in the upcoming election in 2014. As a result, the crisis exposed not only the problems with the management of the Cantareira system but also the system's own low level of adaptiveness. Yet, despite the RBOs weak responses, the crisis in the city of São Paulo may have led to increased adaptive capacity within the Alto Tiete river basin. Water consumption was reduced in the region and additional options for future drought responses were created by building new infrastructure that increased the connections and flexibility of water transfers between basins.

The Piracicaba-Capivari-Jundiaí river basin presents a distinct situation, in that participation was significantly high but had limited influence on actual decisions. While the Alto Tietê RBOs were considerably less participatory, and the use of knowledge limited, in the PCJ river basin, participation was high and the search for customized knowledge much more active. For example, all RBOs meetings and decisions are public and transparent, and there is a high rate of participation by a diverse range of stakeholders. However, these stakeholders seem to have had little sway on the way the main players - ANA, DAEE, and Sabesp - made decisions about allocation and the management of water resources in the basin, especially in response to crisis. Part of the explanation is that the basin is linked to the São Paulo Metropolitan Region (SPMR) water supply through the Cantareira system, which trumps the needs of other users in the basin. Indeed, in this case, Sabesp attempted to control the decisions of both water allocation and supply to the benefit of São Paulo and to the detriment of other users. In this process, Sabesp used its technical dominance to support its claims relative to where water should be allocated. However, this strategy backfired when Sabesp's lack of transparency and inclusion in managing the water supply crisis of 2013-2014 went too far and cast the company in a negative light (Empinotti et al. 2018). As a result, ANA, in agreement with DAEE, intervened and changed the operationalization rules, thereby de facto shifting power to the RBOs to influence water allocation between the two systems. Additionally, the RBOs were able to further limit Sabesp's influence by commissioning their own knowledge to challenge the company's scenarios. In the PCJ river basin, the crisis may have significantly increased the basin's capacity by reasserting the RBOs role relative to the Cantareira system. In addition, the crisis increased the ability of the RBOs information system to seek and produce new knowledge in support of better planning and management in the face of climate-related stress.

In Fig. 2, we return to our heuristic and suggest how our case studies fare in terms of adaptive capacity building.

\section{Conclusions}

Overall, our case studies show that the use of techno-scientific knowledge (TSK) alone is not sufficient to enable good decision-making and governance. The information can become a source of contention when it negatively interacts with other theorized determinants of adaptive capacity, such as participation and democratic deliberation. However, even when it leads to technocratic insulation, the use of TSK can contribute to the building of adaptive capacity to respond to extreme events, albeit in a limited fashion. In this sense, although the Brazilian water reform has contributed to further building capacity of RBOs to respond to extreme events such as drought, the reform still has a long way to go in terms of critically influencing long-term adaptation.

Among the cases in this study, the breadth of CEIVAP has enabled the wide inclusion of actors and issues, which can lead to higher levels of conflict. In the Paraíba do Sul river basin, CEIVAP acts as a forum for sharing information, and there is more equal information access and use among members. While sharing technical information among water management institutions is often problematic, there is less institutionalized competition and control over knowledge. The drought events of 2001-2003 and 2014-2016 mobilized institutional 
responses in a manner that shows the strengths and weaknesses of the reform. On the one hand, CEIVAP represents a success story in terms of production of usable knowledge and increased adaptive capacity. On the other hand, however, the case reveals the limitations of the reform in terms of direct RBOs participation, especially in responding to crises. Despite these limitations, during the 2014-2016 crisis, the ability of the Technical Working Groups and the main actors at higher spheres to negotiate and agree on a feasible plan for water allocation and management across different interests and needs revealed how far the system has come in terms of adaptiveness.

The Médio and Baixo Jaguaribe river basins present the most interesting case in terms of the limited but crucial role of democratic participation in negotiated allocations. This instance of controlled democratization is contrasted with the centralized role of COGERH, which seeks to manage the participation of the RBOs in decision-making, mostly by controlling information. Nonetheless, the sustained negotiated water allocation process represents perhaps one of the most effective features of the reform out of all of the cases. The RBOs' current ability to challenge the prominence of the COGERH técnicos and their scenarios has created new challenges in terms of decision making, and the implications of these challenges with regard to further capacity building are yet to be revealed. Given the magnitude of water scarcity in the region, capacity building is crucial for long-term water security.

Similarly, the cases of Alto Tietê and Piracicaba-CapivariJundiai river basins reaffirmed the importance of the role of knowledge and participatory processes in building on adaptive capacity to respond to crises. While Sabesp's use of knowledge to control the decision-making process prevailed in the Alto Tietê river basins, it backfired in the PiracicabaCapivari-Jundiai river basins and shifted power from Sabesp to the RBOs. However, the need to supply São Paulo with water continues to dominate allocation processes, and the way future crises will be faced is still uncertain. In this sense, these cases illustrate how the responses to crisis expose gaps and challenges that cannot be addressed by adhering to the basic tenets of integrated management. While water reform has clearly opened up decision making and made it more accountable to users, the need to continue building capacity, especially through the use of TSK, requires intentional action from RBOs to keep those who control knowledge in check.

Open Access This article is licensed under a Creative Commons Attribution 4.0 International License, which permits use, sharing, adaptation, distribution and reproduction in any medium or format, as long as you give appropriate credit to the original author(s) and the source, provide a link to the Creative Commons licence, and indicate if changes were made. The images or other third party material in this article are included in the article's Creative Commons licence, unless indicated otherwise in a credit line to the material. If material is not included in the article's Creative Commons licence and your intended use is not permitted by statutory regulation or exceeds the permitted use, you will need to obtain permission directly from the copyright holder. To view a copy of this licence, visit http://creativecommons.org/licenses/by/4.0/.

\section{References}

Abers RN (2007) Organizing for governance: building collaboration in Brazilian river basins. World Dev 35(8):1450-1463. https://doi.org/ 10.1016/j.worlddev.2007.04.008

Abers RN, Keck ME (2006) Muddy waters: the political construction of deliberative river basin governance in Brazil. Int J Urban Reg Res 30:601-622. https://doi.org/10.1111/j.1468-2427.2006.00691.x

ANA, Agência Nacional de Águas (2017) Conjuntura dos recursos hídricos no Brasil 2017: informe anual 2017

Armitage D, Plummer R (2010) Adaptive capacity and environmental governance. Springer. https://doi.org/10.1007/978-3-642-12194-4

Berkes F (2009) Evolution of co-management: role of knowledge generation, bridging organizations and social learning. J Environ Manag 90(5):1692-1702. https://doi.org/10.1016/j.jenvman.2008.12.001

Berkes F, Colding J, Folke C (2000) Rediscovery of traditional ecological knowledge as adaptive management. Ecol Appl 10:1251-1262. https://doi.org/10.2307/2641280

Blomquist W, Dinar A, Kemper K (2005) Comparison of institutional arrangements for river basin management in eight basins. World Bank

Broad K, Pfaff A S, Glantz M H (2002) Effective and equitable dissemination of seasonal-to-interannual climate forecasts: policy implications from the Peruvian fishery during El Nino 1997-98. Climatic Change, 54(4), 415-438. Clim Chang 54:415. https://doi.org/10. 1023/A:1016164706290

Davidson-Hunt IJ, O'Flaherty RM (2007) Researchers, indigenous peoples, and place-based learning communities. Soc Nat Resour 20(4): 291-305. https://doi.org/10.1080/08941920601161312

Empinotti VL, Budds J, Aversa M (2018) Governance and water security: the role of the water institutional framework in the 2013-15 water crisis in São Paulo, Brazil. Geoforum. https://doi.org/10.1016/j. geoforum.2018.09.022

Engle NL (2011) Adaptive capacity and its assessment. Glob Environ Chang 21(2):647-656. https://doi.org/10.1016/j.gloenvcha.2011. 01.019

Engle NL, Lemos MC (2010) Unpacking governance: building adaptive capacity to climate change of river basins in Brazil. Glob Environ Chang 20(1):4-13. https://doi.org/10.1016/j.gloenvcha.2009.07. 001

Engle NL, Johns OR, Lemos MC, Nelson DR (2011) Integrated and adaptive management of water resources: tensions, legacies, and the next best thing. Ecol Soc 16(1)

Folke C, Hahn T, Olsson P, Norberg J (2005) Adaptive governance of social-ecological systems. Annu Rev Environ Resour 30:441-473. https://doi.org/10.1146/annurev.energy.30.050504.144511

Formiga-Johnsson RM, Kumler L, Lemos MC (2007) The politics of bulk water pricing in Brazil: lessons from the Paraíba do Sul basin. Water Policy 9(1):87-104. https://doi.org/10.2166/wp.2006.001

Formiga-Johnsson RM, Lemos MC, Souza Filho FA (2019) Segurança hídrica e capacidade adaptativa urbana e metropolitana em tempos de mudanças climáticas. In: Philippi A Jr, Sobral MC (Org.) Gestão de bacias hidrográficas e sustentabilidade. Editora Manole, São Paulo, p 427-459

Genskow KD, Born SM (2006) Organizational dynamics of river basin partnerships: a key to integrated water resources management. J 
Contemp Water Res Educ 135(1):56-64. https://doi.org/10.1111/j. 1936-704X.2006.mp135001007.x

Hill M (2012) Climate change and water governance: adaptive capacity in Chile and Switzerland. Springer. https://doi.org/10.1007/978-94007-5796-7

Jaspers FGW (2003) Institutional arrangements for integrated river basin management. Water Policy 5(1):77-90. https://doi.org/10.2166/wp. 2003.0004

Kiparsky M, Milman A, Vicuna S (2012) Climate and water: knowledge of impacts to action on adaptation. Ann Rev Environ Resour 37(37): 163-194. https://doi.org/10.1146/annurev-environ-050311-093931

Kirchhoff CJ, Lemos MC, Engle NL (2013) What influences climate information use in water management? The role of boundary organizations and governance regimes in Brazil and the US. Environ Sci Policy 26:6-18. https://doi.org/10.1016/j.envsci.2012.07.001

Knieper C, Pahl-Wostl C (2016) A comparative analysis of water governance, water management, and environmental performance in river basins. Water Resour Manag 30(7):2161-2177. https://doi.org/10. 1007/s11269-016-1276-Z

Lemos MC (2008) Whose water is it anyway? Water management, knowledge, and equity in NE Brazil. Water, Place and Equity, 249-270

Lemos MC (2015) Usable climate knowledge for adaptive and comanaged water governance. Curr Opin Environ Sustain 12:48-52. https://doi.org/10.1016/j.cosust.2014.09.005

Lemos MC, Oliveira JLF (2004) Can water reform survive politics? Institutional change and river basin management in Ceará, Northeast Brazil. World Dev 32(12):2121-2137. https://doi.org/10. 1016/j.worlddev.2004.08.002

Lemos MC, Manuel-Navarrete D, Willems BL, Caravantes RD, Varady RG (2016) Advancing metrics: models for understanding adaptive capacity and water security. Curr Opin Environ Sustain 21:52-57. https://doi.org/10.1016/j.cosust.2016.11.004

Libanio PAC (2018) Two decades of Brazil's participatory model for water resources management: from enthusiasm to frustration. Water Int 43(4):494-511. https://doi.org/10.1080/02508060.2018. 1451695

LoSchiavo AJ, Best RG, Burns RE, Gray S, Harwell MC, Hines EB, McLean AR, St. Clair T, Traxler S, Vearil JW (2013) Lessons learned from the first decade of adaptive management in comprehensive Everglades restoration. Ecol Soc 18(4). https://doi.org/10. 5751/ES-06065-180470

Lundmark C, Jonsson G (2014) Prospects for learning in river management: exploring the initial implementation of the water framework directive in a Swedish river basin. Environ Educ Res 20(2):161176. https://doi.org/10.1080/13504622.2013.780585

Medema W, McIntosh BS, Jeffrey PJ (2008) From premise to practice: a critical assessment of integrated water resources management and adaptive management approaches in the water sector. Ecol Soc 13(2):29

Medema W, Adamowski J, Orr C, Furber A, Wals A, Milot N (2017) Building a foundation for knowledge co-creation in collaborative water governance: dimensions of stakeholder networks facilitated through bridging organizations. Water 9:60. https://doi.org/10. 3390/w9010060
Mishra AK, Singh VP (2010) A review of drought concepts. J Hydrol 391. https://doi.org/10.1016/j.jhydrol.2010.07.012

Morrison TH, Adger WN, Brown K, Lemos MC, Huitema D, Hughes TP (2017) Mitigation and adaptation in polycentric systems: sources of power in the pursuit of collective goals. WIREs Clim Chang 8:e479. https://doi.org/10.1002/wcc.479

Nelson DR, Adger WN, Brown K (2007) Adaptation to environmental change: contributions of a resilience framework. Annu Rev Environ Resour 32:395-419. https://doi.org/10.1146/annurev.energy.32. 051807.090348

Newman L, Dale A (2005) Network structure, diversity, and proactive resilience building: a response to Tompkins and Adger. Ecology And Society, 10 (on line http://www.ecologyandsociety.org/vol10/ iss $1 /$ resp2/)

OECD (2015) Water resources governance in Brazil, OECD Studies on Water. OECD Publishing, Paris. https://doi.org/10.1787/ 9789264238121-en

Olsson P, Folke C (2003) Adaptive comanagement for building resilience in social-ecological systems. Environ Manag 34:75-90. https://doi. org/10.1007/s00267-003-0101-7

Pahl-Wostl C (2007) Requirements for adaptive water management. Adaptive and Integrated Water Management. Coping with Complexity and Uncertainty. Pahl-Wostl C, Kabat P, Moltgen J (editors). Springer Verlag, Heidelberg, Germany, 1-22. https://doi.org/ 10.1007/978-3-540-75941-6 1

Pfaff A, Velez MA, Taddei R, Broad K (2013) Unequal information, unequal allocation: bargaining field experiments in NE Brazil. Environ Sci Policy 26:90-101. https://doi.org/10.1016/j.envsci. 2012.07.002

Savenije HHG, Van der Zaag P (2008) Integrated water resources management: concepts and issues. Phys Chem Earth, Parts A/B/C 33(5): 290-297. https://doi.org/10.1016/j.pce.2008.02.003

Seigerman C, Nelson DR (2019) Produção e uso do conhecimento científico em decisões de alocação de água nas bacias metropolitanas do Jaguaribe e Fortaleza, Ceará. In: de Souza Filho FA, da Silva SMO, Formiga-Johnsson RM, Nelson DR, Nauditt A, Ribbe L (eds) ADAPTA: Gestão adaptiva do risco climático de seca. Expressão Gráfica e Editora, Brazil, pp 541-554

Smit B, Wandel J (2006) Adaptation, adaptive capacity and vulnerability. Glob Environ Chang 16(3). https://doi.org/10.1016/j.gloenvcha. 2006.03.008

Taddei R (2011) Watered-down democratization: modernization versus social participation in water management in Northeast Brazil. Agric Hum Values 28(1). https://doi.org/10.1007/s10460-010-9259-9

Trenberth KE, Asrar GR (2014) Challenges and opportunities in water cycle research: WCRP contributions. Surv Geophys 35(3):515-532. https://doi.org/10.1007/s10712-012-9214-y

Yohe G, Tol RSJ (2002) Indicators for social and economic coping capacity: moving toward a working definition of adaptive capacity. Glob Environ Chang 12(1):25-40. https://doi.org/10.1016/S09593780(01)00026-7

Publisher's note Springer Nature remains neutral with regard to jurisdictional claims in published maps and institutional affiliations. 